Yu.P. Rak, PhD / докт. техн. наук Ю.П. Рак ${ }^{1}$

V.P. Kvashuk / В.П. Квашук ${ }^{2}$

Przyjęty/Accepted/Принята: 31.01.2014;

Zrecenzowany/Reviewed/Рецензирована: 05.06.2014;

Opublikowany/Published/Oпубликована: 30.06.2014;

\title{
RESOURCE MANAGEMENT AND FORECASTING LOSSES WITHIN THE PROJECT ORGANISATIONAL STRUCTURE OF THE CIVIL PROTECTION SYSTEM
}

\author{
Управление ресурсами и прогнозирование потерь \\ в проектно-организационных системах гражданской защити
}

\author{
Zarządzanie zasobami i prognozowanie strat w projektowej strukturze \\ organizacyjnej systemu obrony cywilnej
}

\begin{abstract}
Objective: To develop a method, based on Pareto principles, for increasing resource management effectiveness with prediction and minimisation of losses arising from emergency situations, both industrial and natural within the project-based organisation structure of the civil protection system.

Methods: Theoretical research of an effective management process, with the aid of Pareto distribution, was applied to project organisational structures through the Office of Civil Protection. Current project management tools such as: PMBOK, P2M, PRINCE2, ICB, etc. provided a basis for scientific research. During the research process various methods were applied such as: systems theory, systems analysis, statistical analysis, cognitive analysis theory, mathematical modelling, information technology and management.

Results: Presentation of theoretical and experimental data allowed for the calculation of losses during emergency situations. These were determined with the aid of Pareto distributions and statistical methods, with a focus on minimising and estimating losses more accurately. The developed technique allows for the control of singular as well as global losses, at all phases as well as levels of management within the project office, simultaneously ensuring the mitigation of losses and attainment of a high level of functional effectiveness of the civil protection system. The basis for the developed technique was a mathematical description of characteristic indicators and maximum as well as total losses for the Pareto distribution. This approach revealed credible data which will help to increase the effectiveness of performance in a unified system of civil protection. Results allow for better management decisions, improved predictions and minimisation of losses arising from environmental disasters.

Conclusions: Results from research allowed, on the basis of long term statistical data, to achieve a high degree of convergence. The developed technique, using Pareto distributions, demonstrated that its application to resource management in the civil protection system leads to minimisation of losses during emergency situations and optimisation of the project management process, simultaneously making it possible to anticipate resource losses at all stages. Furthermore, research was harnessed to address current and applied research challenges, which impact on the improvement of project and programme management; optimal allocation of losses and creation of the most favourable conditions for the organisational management of a unified system of civil protection under the auspices of The Office of Civil Protection. The proposed method describes characteristic values of total and maximum losses, which may be used to obtain most accurate and relevant data, which in turn make it possible to minimise errors during management decision making, and significantly enhance the research base for projects and programme management methods . Obtained results will afford an opportunity to consider the unified system of civil protection in Ukraine in context of a project organisation structure.
\end{abstract}

\footnotetext{
${ }^{1}$ Lviv State University of Life Safety; address: Ukraine, 79000, Lviv, Kleparivska St., 35; e-mail: jurarak2012@gmail.com; percentage contribution - 60\%. / Львовский государственный университет безопасности жизнедеятельности. Адрес: Украина, 79000 , Львов, ул. Клепаровская, 35; электронная почта: jurarak2012@gmail.com; фактический вклад - 60 \%.

${ }^{2}$ Lviv State University of Life Safety; address: Ukraine, 01601, Kiev, O. Gonchara St., 55-a; e-mail: kvashuk@mns.gov.ua; percentage contribution - 40\%. / Львовский государственный университет безопасности жизнедеятельности. Адрес: Украина, 01601, м. Киев, ул. О.Гончара 55-а.; фактический вклад - 40 \%.
} 
Keywords: method, maximum and total loss, Pareto, programmes, projects, crisis situations, project management oriented, Office, unified civil protection system

Type of article: original scientific article

\title{
Аннотация
}

Цель: Разработка метода основанного на распределении Парето для целей повышения эффективности управления ресурсами при минимизации и прогнозировании потерь от чрезвычайных ситуаций природного и техногенного характера в проектах, программах и портфелях проектов проектно-организационных систем гражданской защиты.

Методы: Теоретический метод исследования процесса эффективного управления проектно-организационной структурой через офис гражданской защиты с использованием распределения Парето. В основу проведенных научных исследований была применена современная методология управления проектами, программами и портфелями проектов: PMBOK, P2M, PRINCE2, ICB и др. При выполнении исследований использовались методы: теории систем и системного анализа, статистические исследования, теории когнитивного анализа, математическое моделирование, информационные технологии, менеджмент.

Результаты: Существующие подходы и инновационные механизмы информационной поддержки при принятии проектных решений руководителями системы гражданской защиты не разрешают выявить степень и характер неопределенности при выполнении будущих работ в начале фазы цикла реализации проекта. Поэтому возникает необходимость учитывать эти условия неопределенности на стадиях планирования, выполнения или программирования будущих работ которые, в свою очередь требуют разработки надежной методики расчета и управления потерь. В основу разработанной методики должны бить заложены теоретические основы оценки и прогнозирования величины потерь от чрезвычайных ситуаций для цели оперативного принятия управленческих решений и успешной реализации проектов через офис единой системы гражданской защиты Украины. Приведенные теоретические и экспериментальные данные позволили, на основе распределения Парето и статистики, создать универсальную методику расчета потерь, обеспечить их минимизацию и более точное прогнозирование, которые возникают от чрезвычайных ситуаций. Разработанный метод позволяет контролировать как единичные, так и глобальные потери на всех фазах и ярусах, при офисном управлении проектами, программами и портфелями проектов, обеспечивая при этом минимизацию потерь и высокую эффективность функционирования системы гражданской защиты. В основу разработанной методики заложено математическое описание соотношений характерных, максимальных и суммарных потерь для распределения Парето, с целью получения наиболее достоверных данных повышающие эффективность реализации проектов, программ и портфелей проектов через офис единой системы гражданской защиты, и, как результат принимать оптимальные управленческие решения, и, соответственно, более точно прогнозировать и минимизировать потери от возникающих ЧС.

Выводы: Результаты проведённых исследований позволили, на базе многолетних данных статистики, получить высокую сходимость результатов. Разработанный метод с использованием распределения Парето показал, что применения методологии офисного проектно-организационного управления системой гражданской защиты обеспечивает процесс минимизации потерь от чрезвычайных ситуаций и оптимизацию управления проектами, программами и портфелями проектов, обеспечивая при этом возможность прогнозировать ресурсные потери на всех стадиях реализации проектов, программ и портфелей проектов. Кроме того проведено теоретическое исследование в плане выполнения актуальной научно-прикладной задачи повышения эффективности управления проектами и программами: оптимального распределения потерями и создать максимально благоприятные условия управления через Офис единой системы гражданской защити. Предложений метод описывающий характеристику значений суммарных и максимальных потерь позволяет получать наиболее достоверные и оперативные данные, что приведет к минимизации ошибок при принятии управленческих решений, существенно расширит научную базу методологии управления проектами и программами, и даст возможность рассматривать единую систему гражданской защити Украины как проектно-организационную структуру.

Ключевые слова: метод, максимальные и суммарные потери, Парето, программы, проекты, портфель проектов, чрезвычайные ситуации, проектно-ориентированное управление, офис, единая система гражданской защиты

Вид статьи: оригинальная научная работа

\begin{abstract}
Abstrakt
Cel: Opracowanie metody, która opiera się na zasadzie Pareto w celu zwiększenia efektywności zarządzania zasobami przy prognozowaniu i minimalizacji strat wynikających z sytuacji nadzwyczajnych klęsk i katastrof spowodowanych przez człowieka w projektach, programach i portfelach w projektowej strukturze organizacyjnej systemu ochrony cywilnej.

Metody: Badania teoretyczne procesu efektywnego zarządzania za pomocą rozkładu Pareto stosowanego w projektowych strukturach organizacyjnych biura ochrony ludności. Podstawą metodologii badań naukowych jest nowoczesne zarządzanie projektami, programami i portfelami projektów: PMBOK, P2M, PRINCE2, ICB, itp. Podczas badań stosowano metody: teorii systemów i analizy systemów, badania statystyczne, teorii analizy poznawczej, modelowanie matematyczne, informacje technologia oraz zarządzanie.

Wyniki: Zaprezentowane dane teoretyczne i doświadczalne umożliwiły stworzenie na podstawie zasady Pareto i metod statystycznych uniwersalnej metodologii obliczania strat powstałych w sytuacjach kryzysowych w celu zapewnienia ich minimalizacji i bardziej dokładnej prognozy. Opracowana metoda pozwala na kontrolę zarówno pojedynczych jak i globalnych strat we wszystkich fazach i na wszystkich etapach zarządzania biurem projektów, programów i portfeli projektów, jednocześnie zapewniając minimalizację strat i wysoką efektywność funkcjonowania systemu ochrony cywilnej. Podstawą opracowanej techniki był matematyczny opis charakterystycznych wskaźników oraz maksymalnych i całkowitych strat dla rozkładu Pareto, dzięki któremu uzyskano wiarygodne dane zwiększające efektywność projektów, programów i portfeli w jednolitym systemie ochrony cywilnej. Uzyskane wyniki umożliwią podejmowanie lepszych decyzji w zakresie zarządzania, przewidywania i minimalizacji strat wynikających z klęsk żywiołowych.

Wnioski: Wyniki tych badań pozwoliły na podstawie statystyk długoterminowych uzyskać wysokie wyniki konwergencji. Metoda opracowana z wykorzystaniem rozkładu Pareto wykazała, że stosowanie metodologii w zarządzaniu biurem projektów
\end{abstract}


w systemie ochrony cywilnej stanowi proces minimalizacji strat w sytuacjach kryzysowych i optymalizacji zarządzania projektami, programami i portfelami projektów, jednocześnie zapewniając możliwość przewidzenia strat zasobów na wszystkich etapach projektów, programów i portfeli realizacji projektów. Ponadto, badania teoretyczne opierały się na realizacji bieżących i stosowanych problemów naukowych, które wpływają na poprawę zarządzania projektami i programami: optymalną alokację strat i tworzenie jak najkorzystniejszych warunków dla organizacyjnego zarządzania jednolitym systemem ochrony ludności za pośrednictwem Urzędu Ochrony Cywilnej. Proponowana metoda opisuje charakterystyczne wartości całkowitych i maksymalnych strat, dzięki którym możliwe będzie uzyskanie najbardziej dokładnych i aktualnych danych, które będą minimalizować błędy w podejmowaniu decyzji zarządczych, znacznie wzbogacą bazę naukową projektu i metodykę zarządzania programami. Uzyskane wyniki będą również okazją do rozważenia jednolitego systemu ochrony ludności Ukrainy jako projektowej struktury organizacyjnej.

Słowa kluczowe: metoda, maksymalna i całkowita strata, Pareto, programy, projekty, portfolio projektów, sytuacje kryzysowe, zarządzanie zorientowane na projekt, biuro, jednolity system ochrony ludności

Typ artykułu: oryginalny artykuł naukowy

\section{Introduction}

The fast growth of the company is accompanied by the rise of a number of emergency situations (ES), which cause the huge economic losses and casualties. To anticipate and minimize them it is required to introduce a modern methodology of project-oriented management of projects, programmes and portfolios of projects on the basis of a single office of civil protection. The emergencies occur under the conditions of uncertainty due to incomplete information, inaccuracy or ambiguity of data, availability of accidents factors, subjectivity, etc. Therefore, assessing the material, financial or other losses is very difficult and it requires the development of reliable calculating methods.

The existing approaches and mechanisms of information support in making design decisions of civil protection leaders (SCD) does not allow to reveal the extent and nature of the uncertainty of future work by the beginning of the implementation phase of the project, so we must take into account this uncertainty in the process of planning, implementation and programming of the future work, what in turn requires a reliable methodology for calculating losses.

The research of the different aspects of describing the disaster parameters confirmed that their losses in the different phases of the implementation of projects, programmes or portfolios of projects devoted to the work of many scientists, are significantly different from each other. The issues of the projecting, building models and management of projects, programs and portfolios of projects, in the context of complex systems under uncertainty, engaged following domestic and foreign scientists: V.N. Burkov, S.D. Bushuyev, O.P. Ratshteyn, V.A. Rach, O.S. Ponomaryev, R.R. Yager, P.L. Vylenskyy, S.D. Shtovba, K.V. Koshkin, S.K. Chernov and other. However, there are still many insoluble problems related to the impact of uncertainties detailed study of the structural elements of the project on the accuracy of estimation and forecasting losses from disasters. Thus, evaluation and prediction of losses in the managing office SCD with a view to the successful and effective implementation of projects, programs and project portfolios is an urgent task.

\section{Problem setting}

Management effectiveness of civil protection uniform system is possible by creating the necessary preconditions on the basis of established office; manage projects, programmes and portfolios, while ensuring a systematic ap- proach to minimize losses, both on stage and in the prediction of emergency elimination.

Implementation of the above mentioned problems is possible while the developing a reliable method of calculating losses. When it is considered that the existing methods and approaches estimates predict the magnitude of losses from disaster are built on averages of data are inefficient, so we propose to develop a fairly reliable and versatile technique, which is based on Pareto and give mathematically correct and consistent results when they are calculated.

\section{Purpose of research}

The aim of the development has the most universal method for assessing and predicting the magnitude of disaster losses, which is based on the Pareto distribution in order to increase the effectiveness of projects, programmes and project portfolios which are based on the uniform system of civil defense office consisting of the Ukrainian experts, who are able to provide optimal decisions.

\section{Main part of the research}

In the researches [1-4], it is described the use of different types of distributions, mathematically describing parameters and disaster losses produced by them. Divergence get most of their values, which complicates the process of making optimal management decisions to manage projects, programmes and portfolios more effectively by the office of the uniform system of civil defense. Carl Gauss found that the probability distribution of random variables is often described by the same mathematical expression, which is called the Gauss distribution. Differential distribution function has the form of Gauss:

$$
y=\frac{1}{\sigma \sqrt{2 \pi}} e^{-\frac{(x-a)^{2}}{2 \sigma^{2}}}
$$

This type of distribution is well studied and is also called normal and it shows that more deviations can be ignored from the mean values (more than $3 \sigma$ ). Today there are quite a few other probability distributions "tails" which fall off much slower than a normal distribution, they are called "fat tails" $[2 ; 3 ; 4]$. The using of the probability distributions «heavy tails» that describes the slow decay among of the rarest situations, especially to determine the number of human casualties and material losses that arises from the disaster $[4 ; 5 ; 6]$. 
Such distribution is theoretically an infinite mean and therefore the calculations of the average values with the limited samples reveal high instability of these estimates [7]. Therefore, the existing mathematical relationships that defines the magnitude of disaster losses has greater divergence in values and, accordingly, there is no possibility of making optimal management decisions as in all phases of the project and in carrying out the projects, programmes and portfolios as a whole, in the context of obtaining assessment and prediction of losses.

If it is considered that saying above, the basis of our mathematical description of the method of laying of the characteristic ratio, the maximum and the total loss for the Pareto distribution, in order to obtain the most reliable data increase the efficiency of projects, programmes and portfolios through the office of the unified system of civil protection, and as a result, to take certain management decisions, and thus anticipate and minimize losses from disasters.

We assume a certain approximation, that the ES is the Poisson distribution with intensity $\lambda$ events per year. Then arbitrary number ES $n$ will happen over $T$ years, subject to the Poisson distribution with parameters $\lambda, T$. Now we analyze the maximum loss ratio in the time $T, m_{T}$ and the total losses $\sum_{T}$ for the same period of time. For the case of fast (not slower than $\exp (-\delta x)$, where $\delta>0)$ decrease of the probability density can be represented by the form

$$
m_{T} \cong \ln T \pm \delta
$$

As $T \rightarrow \infty$ where: $\delta$-dispersion boundary distribution medians; $\vartheta$ - Constanta. Thus total loss $\sum_{T}$ time-dependent $T$ view:

$$
\sum_{T} \cong T\left(a+\frac{\sigma \xi_{T}}{\vartheta_{T}}\right)
$$

Where $a$ - expectation annual losses; $\sigma$ - its variance; $\xi_{T}-$ Gauss standard random variables with zero mean and unit variance.

Thus, in the absence of "severe degree of tails", the distribution ratio of the total and maximum individual losses are described with some approximate linear increase with time $T$

$$
R(T)=\frac{\sum_{T}}{m_{T}} \cong \frac{a T}{\vartheta \ln (T)}
$$

Quite different picture is observed in the case of "heavy tails" of the distribution. For them, the ratio of $R(T)$ is not growing as fast and it can be assumed constant, which is independent of $T$, that is total and maximum single loss melts comparable in magnitude. For such cases, the actual distribution of the behaviour of such losses are satisfied for large values of $T$, which exceeds the recurrence of events $x$, and corresponds to a threshold level $x>A$. For large $T$, the total losses are defined by the maximum single loss. This approach provides a theoretical jus- tification for the use of the maximum single loss in time $T$ as a simple, theoretically sound assessment of the total loss distribution with "heavy tails".

We give [5] a precise relation between the total and maximum losses in the time $T$ for the case of a Pareto distribution. For this purpose, derived explicit upper and lower bounds for the total loss $\sum_{T}$ and made the transition from the distribution of the maximum and the total loss to the distribution of their logarithms.

Such distribution of single loss which is described in the field of Pareto's enough big distributions, after logarithming of losses, is transformed to exponential distribution with parameter $\beta$ that has all elements of distribution, as well as distribution of logarithms of total loss of $\ln \sum_{T}$.

We will give now exact ratios between total and maximum losses during $T$ for a case of Pareto distribution.

Upper bound. For $\ln \sum_{T}$ we have:

$$
\ln \sum_{T}=\ln R(T)+\ln m_{T}
$$

Where $m_{T}$ - maximum loss for the period $(0, T)$, provided that during this period was not less than a disaster. Take the expectation of the right and left side of the formula (4) we obtain:

$$
E \ln \sum_{T}=E \ln R(T)+E \ln m_{T}
$$

Now it is used a roughness for Jensen concave functions [7], which applies a logarithmic function and obtain the following dependence:

$$
E \ln R(T)<\ln E R(T)
$$

As it is shown in [5]

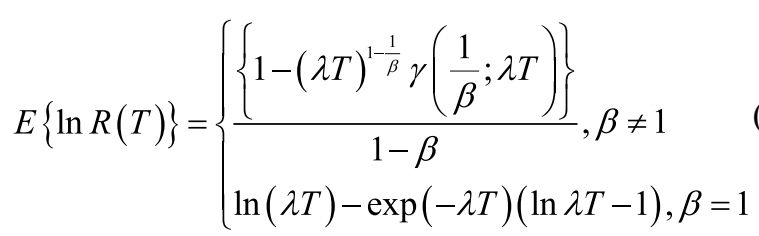

Where $\gamma(\varepsilon, \varphi)$ - incomplete gamma function [8]; at $\lambda T \rightarrow \infty$ incomplete gamma function tends to the usual range of functions $\Gamma\left(\frac{1}{\beta}\right)$ then

$\gamma\left(\frac{1}{\beta}: \lambda T\right)=\int_{0}^{\lambda}\left\{x^{\frac{1}{\beta}-1} \exp (-x) d x\right\} \rightarrow \int_{0}^{\infty}\left\{x^{\frac{1}{\beta}-1} \exp (-x) d x\right\}=\Gamma\left(\frac{1}{\beta}\right)(8)$

For $E \ln \left(m_{T}\right)$ can obtain the following expression [5]

$$
E \ln \left(m_{T}\right)=\frac{\{\ln (\lambda T)+c-E i(-\lambda T)\}}{\beta}
$$

Wherec $c$-Eyler constant $(\mathrm{c} \approx 0,577) ; \operatorname{Ei}(-\lambda T)$ - integral of function declining [8]; 


$$
E i(x)=\int_{-\infty}^{x}\left\{\exp \frac{(z)}{z}\right\} d z, x \leq 0
$$

We combine the expressions (5 and 6), and obtain an upper bound for $E \ln \sum_{T}$, then

$$
E \ln \sum_{T} \leq\left[\frac{1}{1-\beta}\left\{1-(\lambda T)^{1-\frac{1}{\beta}} \gamma\left(\frac{1}{\beta} ; \lambda T\right)\right\}\right]+\frac{\{\ln (\lambda T)+c-E i(-x T)\}}{\beta}(10)
$$

\section{At $\lambda T>1$, expression (10) is simplified}

$$
E \ln \sum_{T} \leq\left\{\begin{array}{l}
\frac{\ln \left\{1-(\lambda T)^{1-\frac{1}{\beta}} \Gamma\left(\frac{1}{\beta}\right)\right\}+\frac{\{\ln (\lambda T)+c\}}{\beta}}{(1-\beta)}, \beta \neq 1 \\
\ln (\gamma T)+\ln (\ln \lambda T)+c, \beta=1
\end{array}\right.
$$
$\lambda T>1$

With estimate for $R(T)$ (7) shows that when $\beta<1$ and

$$
E\{R(T)\} \cong(\beta-1)^{-1}(\lambda T)^{1}
$$

When $\beta<1$ and $\lambda T>1$

$$
E\{R(T)\} \cong(\beta-1)^{-1}(\lambda T)^{1-\frac{1}{\beta}} \Gamma\left(\frac{1}{\beta}\right)
$$

Thus, when $\beta<1$ random variables $\sum_{T}$ and $m_{T}$ are comparable, and their logarithms grow about as $\frac{\ln (\lambda T)}{\beta}=\ln (\lambda T)^{\frac{1}{\beta}}$. This can be interpreted as a linear increase in most units $\sum_{T}$ and $m_{T}$ proportional $(\lambda T)^{\frac{1}{\beta}}$. We recall that in this case $\beta-1$ these are exactly the random $\sum_{T}$ and $m_{T}$ that has an infinite expectation.

At $\beta>1$ and $\lambda T>1 \ln E\{R(T)\}$ and $E\left(\ln m_{T}\right)$ increase with increasing $T$ thus

$$
\begin{gathered}
\ln E\left\{R(T) \cong\left(1-\frac{1}{\beta}\right) \ln (\lambda T)\right\} \\
E \ln \left\{m_{T}\right\} \cong \frac{1}{\beta} \ln (\lambda T)
\end{gathered}
$$

From (14) and (15) it is shown that when $\beta$ is much larger than unity, $E\{R(T)\}$ grows approximately linearly with $T$, and $E m_{T}$ depends rather weakly, as the root of $\beta$-th degree of $T$.

The lower boundary. For the lower limit losses $R(T)$ can be represented in the form

$$
R(T)=\frac{\sum_{T}}{m_{T}}=\sum_{i=1}^{n} \frac{x_{i}}{m_{T}}
$$

Where $n$ - Poisson random number within emergencies $(0, T)$, and $x_{i}-$ the respective values of losses.

Since the arithmetic mean value is always less than the geometric mean, then from (16) we obtain the following expression

$$
\begin{aligned}
& \ln R(T)=\ln \left\{\frac{\ldots}{n \sum_{i=1}^{n} \frac{x_{i}}{m_{T}}}\right\}=\ln (n)+\ln \left(\frac{1}{n \sum_{i=1}^{n} \frac{x_{i}}{m_{T}}}\right) \geq \\
& \geq \ln (n)+\ln \left(\prod_{i=1}^{n} \frac{x_{i}}{m_{T}}\right)^{\frac{1}{n}}=\ln (n)+\frac{1}{n \sum_{i=1}^{n} \ln x_{i}-\ln m_{T}}
\end{aligned}
$$

Taking the expectation of both sides of unequal (17) and making the transformation, respectively, to the Pareto distribution function, we obtain

$$
\begin{gathered}
f(x)= \begin{cases}\left(\frac{\beta}{x^{1+\beta}}\right) ; x \geq 1, \beta>0 \\
0 ; & x<1\end{cases} \\
F(x)=1-\frac{1}{x^{\beta}}
\end{gathered}
$$

For any fixed value $x_{0}=A \cong 1$, where density distribution; $F(x)$ - distribution function, $A>0$ and $\beta>0$ - parameters that affect the continuous probability of distribution the density. Averaging the second term on the righthand side, we obtain

$$
E\{\ln R(T)\} \geq E \ln (n)+\frac{1}{\beta}-E \ln m
$$

Substituting (18) into (5) we obtain a lower bound for $E \ln \sum_{T}$

$$
E \ln \sum_{T} \geq E \ln (n)+\frac{1}{\beta}
$$

For the case of a Poisson process, the mean values of $E \ln (n)$ has the form

$$
E \ln (n)=\sum \frac{\ln (r) \exp _{r=1}^{\infty}(-\lambda T)(\lambda T)^{k}}{k}
$$

On the basis of (20) with $\lambda T>1$, we can get a simple approximate expression for the lower limit $E \ln \sum_{T}$. This approach is based on the fact that the distribution of the random variable $\frac{(n-\lambda T)}{\vartheta(\lambda T)}$ approaches as $T \rightarrow \infty$ to the standard Gaussian distribution of the form 


$$
n \cong \lambda T+\sqrt{(\lambda T) \xi_{T}}=\lambda T\left\{\frac{1+\xi}{(\lambda T)}\right\}
$$

Where $\xi_{T}-$ the standard value of Gause. Hence we obtain the following expression

$$
\ln (n) \cong \ln (\lambda T)+\ln \left\{\frac{1+\xi}{(\lambda T)}\right\} \cong \ln (\lambda T)+\frac{\xi_{T}}{\sqrt{(\lambda T)}}(22)
$$

Now taking expectations of both sides of (22), we obtain

$$
E\{\ln (n)\} \cong \ln (\lambda T)
$$

Substituting this approximation in (19) we obtain a simple estimate of the lower limit $E \ln \sum_{T}$ for $\lambda T>1$

$$
E \ln \sum_{T} \geq \ln (\lambda T)+\frac{1}{\beta}
$$

This approximation can be used only when $\beta>1$, otherwise, when $(\beta<1)$ the expression $E \ln \sum_{T}$ grows at $T \rightarrow \infty$ as about $\ln (\lambda T)^{\frac{1}{\beta}}$.

For $\beta<1$ value $E \ln \sum_{T}$ can be estimated from below using $E\left(\ln m_{T}\right)$ (as there is always the condition $R(T) \geq 1$ )

$$
E\left\{\ln \sum_{T}\right\} \geq E\left\{\ln m_{T}\right\}=\frac{\{\ln (\lambda T)+c-E i(-\lambda T)\}}{\beta}
$$

As a result, the lower bound of the logarithm expectation of the total loss $E \ln \sum_{T}$ is estimating relations (19) and (23) for $\beta>1$ and (24) for $\beta<1$.

The obtained expressions allow estimating the magnitude $\ln \sum_{T}$ with reasonable accuracy. If the distributions in large losses are fairly well approximated by a Pareto distribution, than the zone approximation gives a fairly accurate estimate of the parameter $\beta$. It can be monitored uncertainty, by knowing the error estimates of this parameter, substituting the upper and lower boundaries of the parameter $\beta$ (where $\beta=\widehat{\beta}\left(1 \pm 1,64 \vartheta_{n}\right)$ in the formula to estimate the amount of loss.

It should be noted that the approximation of the Pareto distribution should be choosing a fairly large threshold value $A$, and thus neglect the loss is less than this threshold, can make a significant error in calculations. This error will be greater, than the forecast horizon $T$ is shorter, in such cases it is advisable to calculate losses separately, smaller threshold $A$. Herewith limitations of all statistical moments are guaranteed and can take advantage of the central limit theorems of probability theory, which gives a Gaussian distribution for the loss. Distribution losses below the threshold $A$ may be thus arbitrary. Described technique can be used to predict and evaluate the maximum and the total losses caused by emergencies at any stage (phase) of projects, programs and portfolios.

For example, we apply the proposed methodology for assessing and predicting the losses caused by floods, earthquakes and hurricanes for (1952-2011 years).Losses are expressed as the number of residents that have lost your home due to an emergency. Accumulated $\sum_{T}$, and current maximum loss $m$, are shown on Fig. 1.

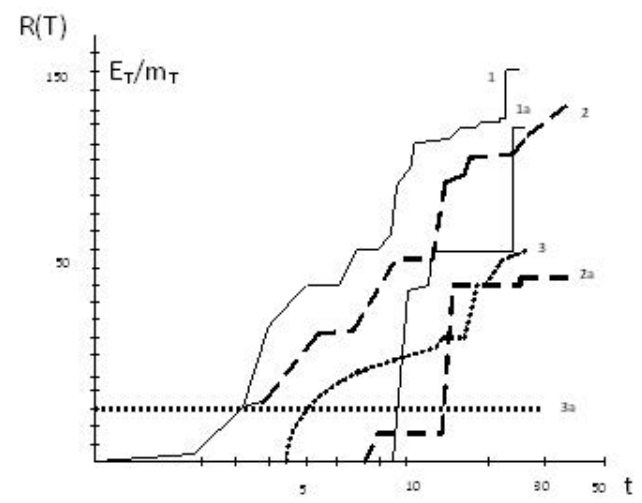

Fig. 1. Accumulation total $\sum_{T}$ and maximum $m_{T}$, losses (based on the number of people left without a roof), depending on the statistical data for $T: 1$ - flood, 2 - hurricanes, 3 - earthquakes,

where $1,2,3$ - values $E_{T} / m_{T}, 1_{\mathrm{a}}, 2,3_{\mathrm{a}}$ - values of $R(T)$

The Image 1 shows that the ratio of these losses in 2011 takes the value $2.29,6.44$, and 4.5 to floods, hurricanes and earthquakes. Number of emergencies (have left more than 50000 homeless inhabitants) for 60 years was respectively 89.68 and 45 events. Comparing the given relationships $E_{T} / m_{T}$, with the theoretical values $R(T)$ with Table 1 (that based on equations (6), (9) and (10) can be obtained preliminary conclusions about the nature of the distributions of the test and the importance of $\beta$. To do this (at $\lambda T=n$ ) must be chosen such $\beta$, at which table value $R$ most closely meets the empirical relation of total and maximum losses. To obtain the data being analyzed: $\beta_{n} \cong 0,6 ; \beta_{y} \cong 1,2 ; \beta_{3} \cong 1,1$; where the indices " $n$ ", " $y$ " and "3" correspond respectively to the flood, hurricanes, earthquakes. In interpreting the $\beta$ must be considered that the empirical values of the total ratios and maximum losses are random component, and thus, the value of $\beta$ is estimated with some error.

Table 1.

Values of $R(T)$ ratio of total losses to the characteristic depending on the parameters $\lambda T$ and $\beta$

\begin{tabular}{|c|c|c|c|c|c|c|}
\hline \multirow{2}{*}{$\beta$} & \multicolumn{6}{|c|}{$\lambda T$} \\
\cline { 2 - 7 } & 10 & 50 & 100 & 300 & 500 & 1000 \\
\hline 3 & 5,77 & 17,93 & 28,82 & 60,7 & 60,7 & 136,62 \\
\hline 2 & 4,6 & 11,52 & 16,7 & 29,7 & 38,8 & 54,97 \\
\hline 1,3 & 3,48 & 6,55 & 8,26 & 11,62 & 13,49 & 16,42 \\
\hline 1,1 & 3,1 & 5,16 & 6,15 & 7,85 & 7,85 & 9,91 \\
\hline 1,0 & 2,88 & 4,49 & 5,18 & 6,28 & 6,78 & 7,48 \\
\hline 0,9 & 2,59 & 3,81 & 4,26 & 4,92 & 5,2 & 5,56 \\
\hline 0,8 & 2,45 & 3,29 & 3,57 & 3,91 & 4,01 & 4,19 \\
\hline 0,6 & 2,02 & 2,33 & 2,4 & 2,45 & 2,46 & 2,48 \\
\hline
\end{tabular}

For comparison, now it is defined the parameters $\beta$ for the Pareto distribution that approximates the "heavytailed" distributions that are analyzed. For this purpose 
we construct in a double logarithmic scale (Fig. 2) graphics "heavy tails" aforesaid distributions that is the dependence of $N\left(x_{i}>x\right)$ from $x$, where $N\left(x_{i}>x\right)$ - the number of observations $x_{i} \ldots x_{n}$ that exceed $x$.

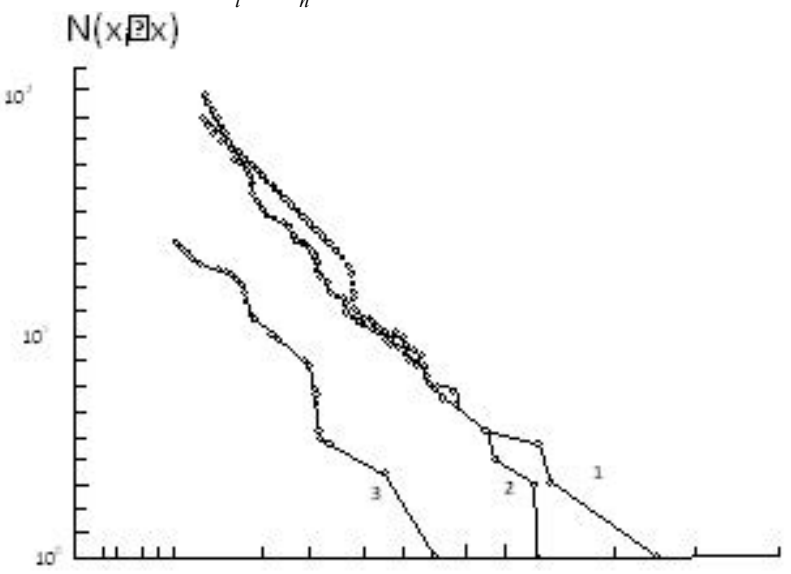

Fig. 2. A graph of the disasters number $N\left(x_{i}>x\right)$, where the losses $x_{i}$ exceed the values $x$, for these statistics: 1 - floods, 2 - hurricanes, 3 - earthquakes

In the case of flood the loss values well lie on a straight line. Linear approximation for hurricanes over the entire range of loss does not stick and is performed only for the tail of the distribution at large $x, A=280000$. Used data for the earthquakes does not provide a reliable approximation of the Pareto law. In this case, we use $A=200000$, but the appraisal $\beta$ comes unreliable due to the small numbers and large scatter losses that exceed a chosen threshold. Value $\beta$ and its error for all three distributions must be calculated according to the formulas

$$
\begin{aligned}
& \widehat{\beta}=\left(\frac{1}{n} \sum \ln \left(\frac{x_{i}}{A}\right)^{-1}\right) \\
& \beta=\widehat{\beta}\left(1 \pm 1,64 / \vartheta_{n}\right)
\end{aligned}
$$

Whereby we obtain:

$$
\begin{aligned}
& \beta_{n}=0,84 \pm 0,09, n=89, A=50000 \\
& \beta_{y}=1,22 \pm 0,22, n=32, A=280000 \\
& \beta_{3}=1,11 \pm 0,29, n=12, A=20000
\end{aligned}
$$

The obtained $\beta$ values correspond for fairly well defined on the basis of the Table 1 analysis, but the second method allows estimating $\beta$. We noted that the data used are examples of all possible types of $\beta$ : $\beta<1, \beta>1$ and $\beta \cong 1$.

Now we turn to the definition of median maximum losses. Taking into account of the duration the output data sets, we define $\mu_{1}$ and $\mu_{20}$ (where $\mu$ - unit losses). The results of evaluations conducted after the calculations are given in Table 2 . For typical values of flood $\mu_{1}$ and $\mu_{20}$ is calculated from the respective Pareto distribution by the formula:

$$
\mu_{T} \cong A(\lambda T / \ln (2))^{1 / \beta}
$$

For hurricanes and earthquakes agreement with the distribution of Pareto is noticeably worse. Therefore, the corresponding values $\mu_{1}$ and $\mu_{20}$ is not evaluated by the parametric method, and based on the use of data that exceed the value above the boundary values of $A$.

Comparing $\mu_{1}$ and $\mu_{20}$ from Table 2 we watch that the flood has been a significant increase in non-linear characteristic values of losses. For hurricanes and earthquakes nonlinearity are significantly weaker, if at all it takes place. This discrepancy corresponds to the difference in the values of the parameter $\beta$ - for hurricanes and earthquakes, where $\beta \cong 1$ or even $\beta>1$.

In the last two columns of Table 2 presents the estimates of the total loss in 20 years, as well as actually observed data loss values. Divergence of estimates and sampling (random) loss values showed a high convergence results.

\section{Conclusions}

The carried out researches helped to create a universal methodology for calculating losses that arise when an emergency occurs. The proposed technique allows controlling both single and global loss in all phases of project management, programmes and portfolios through the office of uniform system of civil defense. Furthermore the proposed method, which is based on Pareto, allows performing forecasting, both the initialization phase of projects, programs and portfolios of projects and in their implementation, and therefore minimize potential losses from occurring emergencies.

The proposed method is based on the Pareto distribution extending the methodology in the management of projects, programmes and portfolios, and allows you to treat Ukraine as uniform system of civil defense project and organizational structure.

Table 2.

Results of the losses calculation for specific cases

(for example floods, hurricanes and earthquakes)

\begin{tabular}{|l|c|c|c|c|c|c|c|c|c|c|}
\hline $\begin{array}{c}\text { Type of } \\
\text { disaster }\end{array}$ & Years & $\begin{array}{c}\text { Border } \\
\boldsymbol{A} \\
\text { thou. }\end{array}$ & $\begin{array}{c}\text { Number of } \\
\text { disasters } \\
\boldsymbol{\lambda}_{\boldsymbol{A}}\end{array}$ & $\boldsymbol{\lambda}$ & $\begin{array}{c}\boldsymbol{\mu}_{\boldsymbol{I}} \\
\text { thou. }\end{array}$ & $\begin{array}{c}\boldsymbol{\mu}_{\mathbf{2 0}} \\
\text { thou. }\end{array}$ & $\boldsymbol{\beta}$ & $\boldsymbol{R}(\mathbf{2 0})$ & $\begin{array}{c}\text { Rating } \\
\text { thou. }\end{array}$ & $\begin{array}{c}\text { Observation } \sum_{\mathbf{2 0}} \\
\text { thou. }\end{array}$ \\
\hline Floods & $1960-1961$ & 50 & 89 & 2,78 & 80 & 9250 & 0,84 & 3,56 & 33000 & 30000 \\
\hline Hurricanes & $1952-2011$ & 280 & 32 & 0,8 & 670 & 4650 & 1,22 & 4,0 & 18600 & 18000 \\
\hline Earthquakes & $1960-2011$ & 200 & 12 & 0,375 & 447 & 11000 & 1,11 & 2,84 & 3200 & 5000 \\
\hline
\end{tabular}




\section{Literature}

1. Modeling economic dynamics: risk, optimization, forecasting [Text]: monograph, V.N. Burkov, O.G. Golichenko, O.F. Kwon, D.A. Kononov (red.) Nizhegorodtseva; MSU of Lomonosov, Center societies. Sciences. Moscow: Dialog-MGU, 1997, p.15.

2. Creative technologies of project and program management: monograph, Bushuyev S.D., Bushueva N.S., Babaev I.A., Yakovenko V.B., Grisha E.S., Dziuba S.V., Voytenko A.S., in: K.: Summit-Book, 2010, p. 768.

3. Azarov N.Ya., Yaroshenko F.A., Bushuyev S.D., Innovative governance mechanisms, Archibald R. Managing high-tech programs and projects / R. Archibald [1n. from English. EV Mamontov; under red. Bazhenova A.D., Aref'eva A.O.]. M.: IT Co., DMK Press, 2004. - 472 p.

4. Management of innovative activity of enterprises and organizations of the sea economic complex [Text], S.I. Bai, V.S. Blintsov, S.D. Bushuev, O.N. Voznyy, A.Yu. Haida, I.M. Zaporozhets, B.Yu. Kozyr, A.V. Kosenko, K.V. Koshkin, M.V. Maslak, P. G. Pererva, I.P. Pokotylov, S.S. Ryzhkov, M.V. Fateev, S.K. Chernov, L.S. Chernova, V.S. Shovkalyuk, H. Tanaka, Nikolaev: publisher Torubara A.S., 2013, p. 448.

5. Rodkyn M., Shebalin N., The mode of natural disasters, "Nature" Issue 6, 1993.

6. Pisarenko V., Rodkin M., About the types of apportionment parameters of natural disasters, "Geoecology" Issue 61996.

7. Pisarenko V., On the best statistical evaluation of the maximum possible magnitude of the earthquake, "Reportsof RAN" Volume 344 Issue 2

8. Pisarenko V., Shapiro M., The types of parameters distribution of natural disasters, "Geoecology" Issue 61996.

9. Turcotte D., Moddeling Geomorphic Processes, "Physica D” Volume 77 1994, pp. 229-237.

10. Kuznetsov I., Pisarenko V., Rodkin M., Methods for calculating the damage from various types of disasters, "Economics and Mathematical Methods", Volume 33 Issue 4, pp. 3945.

11. Risk Management: Risk. Sustainable development. Synergetics, "Kibernetika: unlimited possibilities and potential limitations"), Moscow: Nauka, 2000, p. 431.

12. Rao S., Linear statistical methods and their application, Moscow: Nauka, 1968.
Rak Yuri (Ph.D.) - head of project management, information technologies and telecommunications department in Lviv State University of Life Safety, PhD, Professor, Honored educational worker of Ukraine, Academician of the International Academy of Computer Science and Systems. Sphere of scientific interests: project management, information technologies, cybernetics, automatic control system, modernization of the life safety and civil protection, geometric modeling. The author (co-author) of more than 150 scientific publications.

Kvashuk Vasil - postgraduate of Lviv State University of Life Safety. Sphere of scientific interests: project management, information technologies, modernization of the life safety and civil protection. 